\title{
Biological Treatment of Textile Effluent Using Candida zeylanoides and Saccharomyces cerevisiae Isolated from Soil
}

\author{
O. P. Abioye, O. T. Mustapha, and S. A. Aransiola \\ Department of Microbiology, Federal University of Technology, PMB 65, Minna 920281, Nigeria \\ Correspondence should be addressed to O. P. Abioye; bisyem2603@yahoo.com
}

Received 20 May 2014; Accepted 14 August 2014; Published 25 August 2014

Academic Editor: Olimpia Pepe

Copyright (C) 2014 O. P. Abioye et al. This is an open access article distributed under the Creative Commons Attribution License, which permits unrestricted use, distribution, and reproduction in any medium, provided the original work is properly cited.

\begin{abstract}
This study evaluates the efficacy of yeasts isolated from soil in the treatment of textile wastewater. Two yeast species were isolated from soil; they were identified as Candida zeylanoides and Saccharomyces cerevisiae. The yeasts were inoculated into flask containing effluent and incubated for 15 days. Saccharomyces cerevisiae showed the most significant treatment capacity with a $66 \%$ reduction in BOD; this was followed closely by Candida zeylanoides with $57.3 \%$ reduction in BOD and a consortium of the two species showed the least remediation potential of $36.9 \%$. The use of Saccharomyces cerevisiae and Candida zeylanoides in treatment of textile wastewater will help to limit the adverse environmental and health implications associated with disposal of untreated effluent into water bodies.
\end{abstract}

\section{Introduction}

Water is required by many industries in great volume; however, a very small fraction is actually consumed, while the greater fraction is ultimately discharged as effluent. The textile industry generates large amount of this effluent during textile production processes such as grinning, spinning, and weaving for the production of bed spread, pillow case, polyester/cotton fabrics, and so on, which requires high volume of water that eventually results in high wastewater generation [1], the release of which poses serious health and environmental concern particularly in developing countries (Nigeria).

Several methods have been used in the treatment of textile effluents in order to achieve decolorization; they include physiochemical methods such as filtration, specific coagulation, use of activated carbon, and chemical flocculation. Some of these methods are effective, that is, they have direct effective decolourization, but quite expensive with other regular operational problems such as low efficiency and inapplicability to a wide variety of dye $[2,3]$. However, biological treatment offers a cheaper and more environmental friendly alternative. In most developing countries like Nigeria, most industries dispose their effluents without treatment. These industrial effluents have hazardous effects on water quality, habitat quality, and complex effects on flowing water [4].
In Nigeria, main contributors to the surface and ground water pollution are the by-products of various industries such as textile, metal, dying chemicals, fertilizers, pesticides, cement, petrochemical, energy and power, leather sugar processing, mining, and others. The discharge of industrial effluents, municipal sewage, and farm and urban wastes carried by drains and canals to rivers worsens and broadens water pollution [5].

Fungi have been attracting a growing interest for biological treatment of waste water ingredients such as metals, inorganic nutrient, and organic compounds through biosorption, biodegradation, bioaccumulation, and enzymatic mineralization [6,7]. Effluent discharge from textile and dyestuff industries to neighboring water bodies has become an important issue primarily due to increasing environmental considerations that has become a public and scientific concern in the light of evidence of their extremely toxic effect on humans and biological ecosystem [8]. Effluent from various sources contaminates water and is associated with heavy disease burden [9]; this can be linked to current shorter life expectancy in the developing countries compared with developed nations [10]. High values of chemical oxygen demand $(\mathrm{COD})$ and biological oxygen demand $\left(\mathrm{BOD}_{5}\right)$ and presence of particulate matter and oil and grease in the effluent cause depletion of dissolved oxygen, which has an adverse effect on the aquatic system and also inhibits the 
activity and growth of microorganisms [11]. Effluent from textile mills also contains chromium, which has a cumulative effect and higher possibilities of entering into the food chain. Due to usage of dyes and chemicals, effluents are dark in colour, which increase the turbidity of water body. This in turn reduces sunlight penetration which hampers the photosynthesis process, causing alteration in the habitat and toxicity of fish and mammals [12]. This research work is aimed at isolating yeasts species from the soil and using them in biological treatment of textile effluent.

\section{Materials and Methods}

2.1. Sample Collection and Preservation. Soil samples were collected from the upper $(20-30 \mathrm{~cm})$ layer of vegetable garden behind the staff quarters of Federal University of Technology (FUT) Minna, Nigeria, in a sterile polythene bag. The effluent was collected in sterile 25 liters plastic container from Funtua textile mill, Katsina state, Nigeria. Samples were preserved by refrigeration at $4^{\circ} \mathrm{C}$ without any preliminary treatment or chemical addition.

2.2. Isolation and Characterization of Yeast Isolates. Pour plate technique was used for the isolation of yeast from the soil sample collected following serial dilution. The yeast colonies that developed on sabouraud dextrose agar (SDA) were isolated and purified by further streaking on sabouraud dextrose agar. Identification of the colonies was carried out by gram staining and wet mount and the well-grown colonies were maintained on SDA slant and stored in the refrigerator. The isolates were also characterized based on their cell morphology, carbohydrate fermentation, and growth at $37^{\circ} \mathrm{C}$. Identification of the isolates was determined by the scheme of Barnett et al. [13].

2.3. Physicochemical Characterization of Textile Effluent. Characterization of the effluent for various parameters such as turbidity, conductivity, total dissolved solids (TDS), biological oxygen demand (BOD), chemical oxygen demand (COD), nitrate, phosphorus, sulphate, and phosphate was carried out using standard methods before and after treatment by yeast isolates to measure reduction in these parameters.

2.4. Decolorization Studies. $100 \mathrm{~mL}$ of the textile waste water was dispensed into nine already sterilized Erlenmeyer flasks each and then inoculated with $5 \mathrm{~mL}$ of 24-hour yeast isolates grown in broth medium as labeled. The flasks were cocked with sterile cotton wool and incubated at room temperature for 15 days. Samples were drawn aseptically at 5-day interval over 15 days for observation. Decolorization of the effluent was determined by monitoring the decrease in several parameters (COD, $\mathrm{BOD}, \mathrm{TDS}, \mathrm{NO}_{3}, \mathrm{PO}_{4}$, sulphate, etc.) as well as the absorbance of the effluent at the effluents predetermined $\lambda_{\max } 450 \mathrm{~nm}$ using a UV-visible spectrophotometer by centrifuging at $5000 \mathrm{rpm}$ for 15 minutes and quantitatively analyzing the absorbance of the supernatant. Distilled water was used as blank and decolorization activity was calculated [14].
TABLE 1: Absorbance of effluent.

\begin{tabular}{lccc}
\hline \multirow{2}{*}{$\begin{array}{l}\text { Incubation } \\
\text { period }\end{array}$} & \multicolumn{3}{c}{ Absorbance at $450 \mathrm{~nm}\left(\lambda_{\max }\right)$} \\
\hline Day 0 & C. zeylanoides & S. cerevisiae & Consortium \\
Day 5 & 0.524 & 0.524 & 0.524 \\
Day 10 & 0.564 & 0.560 & 0.605 \\
Day 15 & 0.499 & 0.463 & 0.542 \\
\hline
\end{tabular}

\section{Results and Discussion}

3.1. Decolorization Assay. Table 1 shows the absorbance of the effluent. At day 5 the absorbance of all the samples was high (0.524); subsequently their absorbance reduced with Saccharomyces cerevisiae showing the most significant treatment rate with absorbance of 0.391 while a consortium of both Candida zeylanoides and Saccharomyces cerevisiae showed the least absorbance of 0.502 .

3.2. Physicochemical Characterization of Textile Effluent. Table 2 shows the physicochemical parameters of the raw textile waste water (effluent) and the parameters following treatment by Candida zeylanoides (sample A), Saccharomyces cerevisiae (sample B), and a consortium of both (Sample C) at the end of days 5,10 , and 15 , respectively.

3.3. Percentage BOD Reduction. Table 3 shows the percentage BOD reduction by Candida zeylanoides, Saccharomyces cerevisiae, and the consortium. The percentage BOD reduction concentration was observed in treatment by the consortium (38.9\%) while Saccharomyces cerevisiae shows the highest percentage BOD reduction (66\%), followed by Candida zeylanoides $(57.3 \%)$.

The effluent collected from Funtua textile mill, Katsina, was pale yellowish in colour, with a conductivity of $14.35 \mu \mathrm{s} / \mathrm{cm}$ indicating high amount of total dissolved solid. TDS (9710 mg/L), BOD (824 mg/L), and COD $(2060 \mathrm{mg} / \mathrm{L})$ were quite high and this could indicate a broad range of chemical contaminants. Phosphorus, phosphate, nitrate, and sulphate of the effluent were $0.86 \mathrm{mg} / \mathrm{L}, 2.64 \mathrm{mg} / \mathrm{L}$, $256.8 \mathrm{mg} / \mathrm{L}$, and $30 \mathrm{mg} / \mathrm{L}$, respectively (Table 2 ). The analysis of the physicochemical parameters showed a high amount as compared to World Health Organization [10] and Environmental Protection Agency (EPA) standards.

BOD and COD tests widely adopted as a measure of pollution effect are measures of the relative oxygendepletion effect of a waste water contaminant. The high COD $(2060 \mathrm{mg} / \mathrm{L})$ and BOD $(824 \mathrm{mg} / \mathrm{L})$ level in the textile effluent analyzed indicated the toxicity level of the effluent and this is very harmful for the whole ecology and aquatic system of the receiving water bodies. The reduction in BOD and COD level after treatment with the yeast isolates could be as a result of removal of organic load from the effluent and ultimately the toxicity as stated by Ong et al. [15].

Reduction in the concentration of TDS by both isolates and their consortium was nearly fifty percent which was in correlation with the work of Ali et al. [16] and Kumar et al., 
TABle 2: Physicochemical characteristics of the textile effluent.

\begin{tabular}{lccccccccccc}
\hline $\begin{array}{l}\text { Sample } \\
\text { parameters }\end{array}$ & \multirow{2}{*}{ Unit } & \multirow{2}{*}{ Raw effluent } & \multicolumn{3}{c}{ Candida zeylanoides } & \multicolumn{3}{c}{ S. cerevisiae } & \multicolumn{3}{c}{ Consortium } \\
& & & Day 5 & Day 10 & Day 15 & Day 5 & Day 10 & Day 15 & Day 5 & Day 10 & Day 15 \\
\hline Turbidity & $\mathrm{NTU}$ & 309 & 182 & 313 & 58.7 & 306 & 342 & 264 & 222 & 147 & 185 \\
TDS & $\mathrm{g} / \mathrm{L}$ & 9.71 & 7.30 & 6.41 & 5.57 & 6.42 & 5.51 & 5.17 & 6.41 & 5.26 & 4.57 \\
Conductivity & $\mu \mathrm{s} / \mathrm{cm}$ & 14.35 & 10.89 & 9.56 & 8.30 & 9.54 & 8.19 & 7.74 & 9.60 & 7.83 & 6.81 \\
$\mathrm{BOD}$ & $\mathrm{mg} / \mathrm{L}$ & 824 & 780 & 520 & 352 & 684 & 440 & 280 & 814 & 572 & 520 \\
$\mathrm{COD}$ & $\mathrm{mg} / \mathrm{L}$ & 2060 & 1950 & 1300 & 880 & 1710 & 1100 & 700 & 2030 & 1430 & 1300 \\
Sulphate & $\mathrm{mg} / \mathrm{L}$ & 30.0 & 30 & 20 & 19 & 57 & 30 & 28 & 26 & 18 & 16 \\
$\mathrm{PO}_{4}$ & $\mathrm{mg} / \mathrm{L}$ & 2.64 & 2.45 & 2.37 & 2.10 & 4.75 & 3.6 & 3.23 & 2.48 & 2.5 & 2.38 \\
Phosphorus $^{*}$ & $\mathrm{mg} / \mathrm{L}$ & 0.86 & 0.80 & 0.77 & 0.69 & 1.55 & 1.18 & 1.05 & 0.81 & 0.81 & 0.78 \\
$\mathrm{NO}_{3}$ & $\mathrm{mg} / \mathrm{L}$ & 256.8 & 187.8 & 107.6 & 75.9 & 124.3 & 56.4 & 33.7 & 101.5 & 53.2 & 30.3 \\
\hline
\end{tabular}

TDS: total dissolved solid.

BOD: biological oxygen demand.

COD: chemical oxygen demand.

TABLE 3: Percentage BOD reduction by yeast isolates.

\begin{tabular}{lccc}
\hline Test organism & Initial BOD & Final BOD & $\begin{array}{l}\text { \% BOD } \\
\text { removal }\end{array}$ \\
\hline $\begin{array}{l}\text { Candida } \\
\text { zeylanoides }\end{array}$ & 824 & 352 & 57.3 \\
$\begin{array}{l}\text { Saccharomyces } \\
\text { cerevisiae }\end{array}$ & 824 & 280 & 66.0 \\
Consortium & 824 & 520 & 36.9 \\
\hline
\end{tabular}

[17] who obtained similar result. The decrease in turbidity level for the treated effluent to 58.7, 264, and 185 by Candida zeylanoides, Saccharomyces cerevisiae, and the consortium, respectively, could be as a result of reduction in organic load as well as available nutrients. Nitrate, sulphate, and phosphate reduced following the 15 days of treatment as they were probably used up as a source of nitrogen, sulphur, and phosphorus by the yeasts. Also, the initial nitrate- $\mathrm{NO}_{3}$ concentration prior to treatment $(256.8 \mathrm{mg} / \mathrm{L})$ could be a source of eutrophication for receiving water as the obtained values exceeded the recommended limit for FEPA [18].

Out of the three treatments, Saccharomyces cerevisiae showed the most significant reduction in BOD $(280 \mathrm{mg} / \mathrm{L})$ and COD $(700 \mathrm{mg} / \mathrm{L})$ values; this could be as a result of the adsorption of anionic dyes in effluent which may be due to the nitrogen containing (or protein) group that comprise the yeast biomass and other cellular components of the organism as suggested by Kumari and Abraham [19]. Candida zeylanoides had the highest reduction in turbidity (58.7), phosphate $(2.10 \mathrm{mg} / \mathrm{L})$, and phosphorus $(0.69 \mathrm{mg} / \mathrm{L})$.

The consortium also offered a considerable advantage over the pure cultures in the reduction of nitrate $(30.3 \mathrm{mg} / \mathrm{L})$, sulphate $(16 \mathrm{mg} / \mathrm{L})$, and TDS $(4570 \mathrm{mg} / \mathrm{L})$ (Table 2). The nitrate reduction by the consortium could be greatly affected by presence of Saccharomyces cerevisiae which also showed a high nitrate reduction rate as a pure culture.

The result generally indicates that, as the days for the treatment of the effluent increased, the physicochemical parameters reduced. Hence, the longer the incubation period with the yeast isolates, the lesser the pollution parameters in the effluent.

\section{Conclusion}

The data obtained from this study indicated that effluents obtained from textile industry (Funtua mill) are highly polluted. The result also confirmed that yeasts are capable of biological treatment of effluent and, as the days for the treatment increased, the physicochemical parameters (pollution indicators) reduced. The highest BOD reduction was seen in Saccharomyces cerevisiae, thus making it a better alternative over Candida zeylanoides and a consortium of both.

\section{Conflict of Interests}

The authors declare that there is no conflict of interests regarding the publication of this paper.

\section{References}

[1] S. M. Ghoreishi and R. Haghighi, "Chemical catalytic reaction and biological oxidation for treatment of non-biodegradable textile effluent," Chemical Engineering Journal, vol. 95, no. 1, pp. 163-169, 2003.

[2] T. Do, J. Shen, G. Cawood, and R. Jeckins, "Biotreatment of textile effluent using Pseudomonas sp. immobilized on polymer supports," in Advances in Biotreatment for Textile Processing, University of Georgia Press, Athens, Ga, USA, 1st edition, 2003.

[3] J. Maier, A. Kandelbauer, A. Erlacher, A. Cavaco-Paulo, and G. M. Gübitz, "A new alkali-thermostable azoreductase from Bacillus sp. strain SF," Applied and Environmental Microbiology, vol. 70, no. 2, pp. 837-844, 2004.

[4] J. P. Bound and N. Voulvoulis, "Household disposal of pharmaceuticals as a pathway for aquatic contamination in the United Kingdom," Environmental Health Perspectives, vol. 113, no. 12, pp. 1705-1711, 2005. 
[5] Environmental Protection Agency (EPA), "Quality Criteria for water, United State of American," 2013.

[6] C. Lacina, G. Germain, and A. N. Spiros, "Utilization of fungi for biotreatment of raw wastewaters," African Journal of Biotechnology, vol. 2, no. 12, pp. 735-753, 2003.

[7] N. Das and D. Charumathi, "Remediation of synthetic dyes from wastewater using yeast-an overview," Indian Journal of Biotechnology, vol. 11, no. 4, pp. 369-380, 2012.

[8] K. Anazawa, Y. Kaida, Y. Shinomura, T. Tomiyasu, and H. Sakamoto, "Heavy-metal distribution in river waters and sediments around a "Firefly Village", Shikoku, Japan: application of multivariate analysis," Analytical Sciences, vol. 20, no. 1, pp. 7984, 2004.

[9] A. I. Okoh, E. E. Odjadjare, E. O. Igbinosa, and A. N. Osode, "Wastewater treatment plants as a source of microbial pathogens in receiving watersheds," African Journal of Biotechnology, vol. 6, no. 25, pp. 2932-2944, 2007.

[10] WHO, Water and Health in Europe: A Joint Report from the European Environment. World Health Organisation, European series no. 93, WHO Regional Publication, 2002.

[11] S. Palamthodi, D. Patil, and Y. Patil, "Microbial degradation of textile industrial effluents," African Journal of Biotechnology, vol. 10, no. 59, pp. 12687-12691, 2011.

[12] E. Joseph, "Wastewater treatment in the textile industry," Dyeing Printing and Finishing, vol. 10, pp. 60-66, 2007.

[13] J. A. Barnett, R. W. Payne, D. Yarrow, and B. Linda, Yeasts: Characteristics and Identification, Amazon.com: Books, 2004.

[14] R. G. Saratale, G. D. Saratale, D. C. Kalyani, J. S. Chang, and S. P. Govindwar, "Enhanced decolorization and biodegradation of textile azo dye Scarlet $\mathrm{R}$ by using developed microbial consortium-GR," Bioresource Technology, vol. 100, no. 9, pp. 2493-2500, 2009.

[15] S. Ong, E. Toorisaka, M. Hirata, and T. Hano, "Decolorization of Orange II using an anaerobic sequencing batch reactor with and without co-substrates," Journal of Environmental Sciences, vol. 24, no. 2, pp. 291-296, 2012.

[16] N. Ali, A. Hameed, S. Ahmed, and A. G. Khan, "Decolorization of structurally different textile dyes by Aspergillus niger SA1," World Journal of Microbiology and Biotechnology, vol. 24, no. 7, pp. 1067-1072, 2008.

[17] R. P. Kumar, L. B. Pinto, and R. K. Somashekar, "Assessment of the efficiency of sewage treatment plants: a comparative study between nagasandra and mailasandra sewage treatment plants," Journal of Kathmandu University for Science Engineering and Technology, vol. 6, no. 2, pp. 115-125, 2010.

[18] Federal Environmental Protection Agency (FEPA), Water Quality, Federal Water Standards, Guidelines and Standard for Environmental Pollution Control in Nigeria. National Environmental Standards. Part 2 and 3, Government Press, Lagos, Nigeria, 2003.

[19] K. Kumari and T. E. Abraham, "Biosorption of anionic textile dyes by nonviable biomass of fungi and yeast," Bioresource Technology, vol. 98, no. 9, pp. 1704-1710, 2007. 

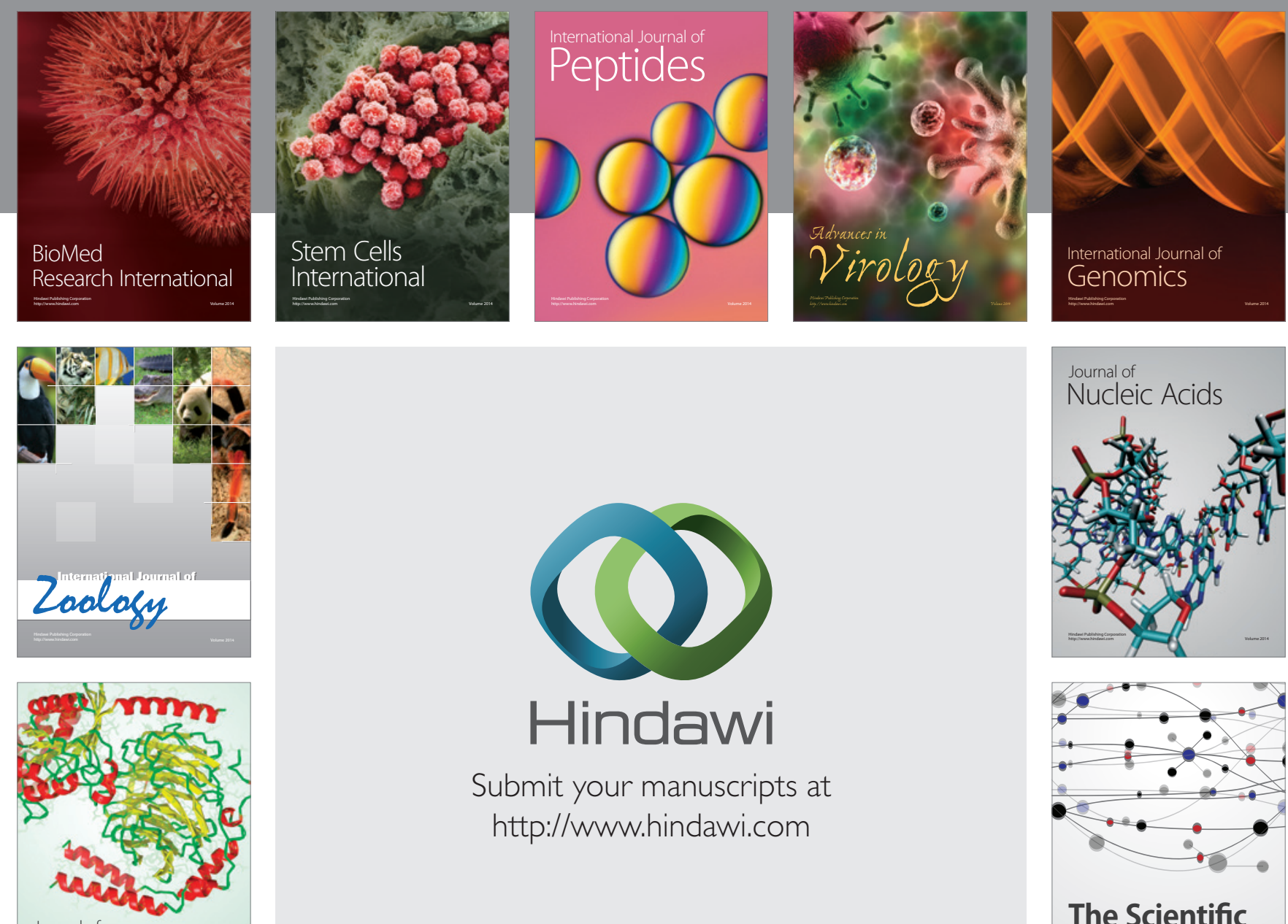

Submit your manuscripts at

http://www.hindawi.com

Journal of
Signal Transduction
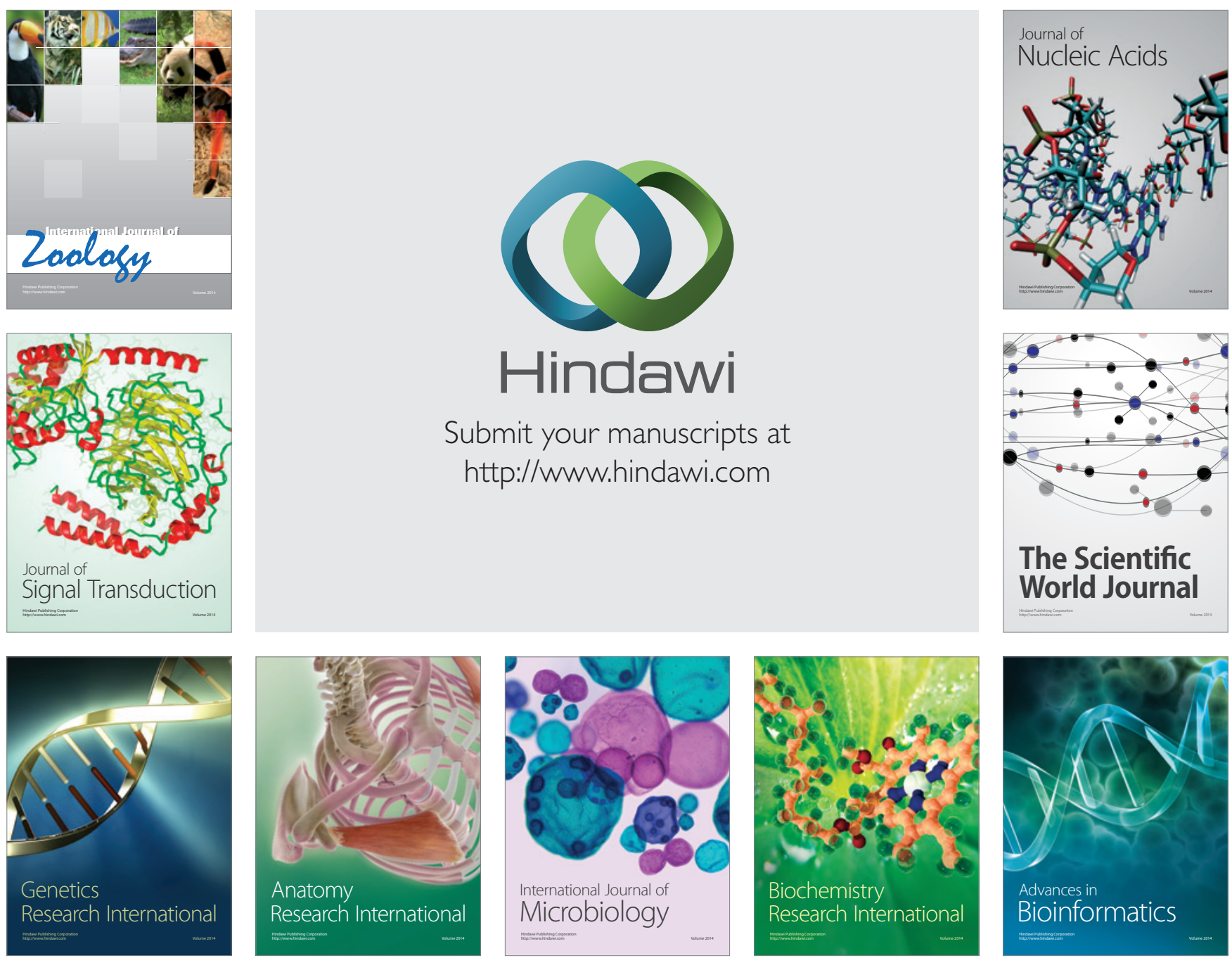

The Scientific World Journal
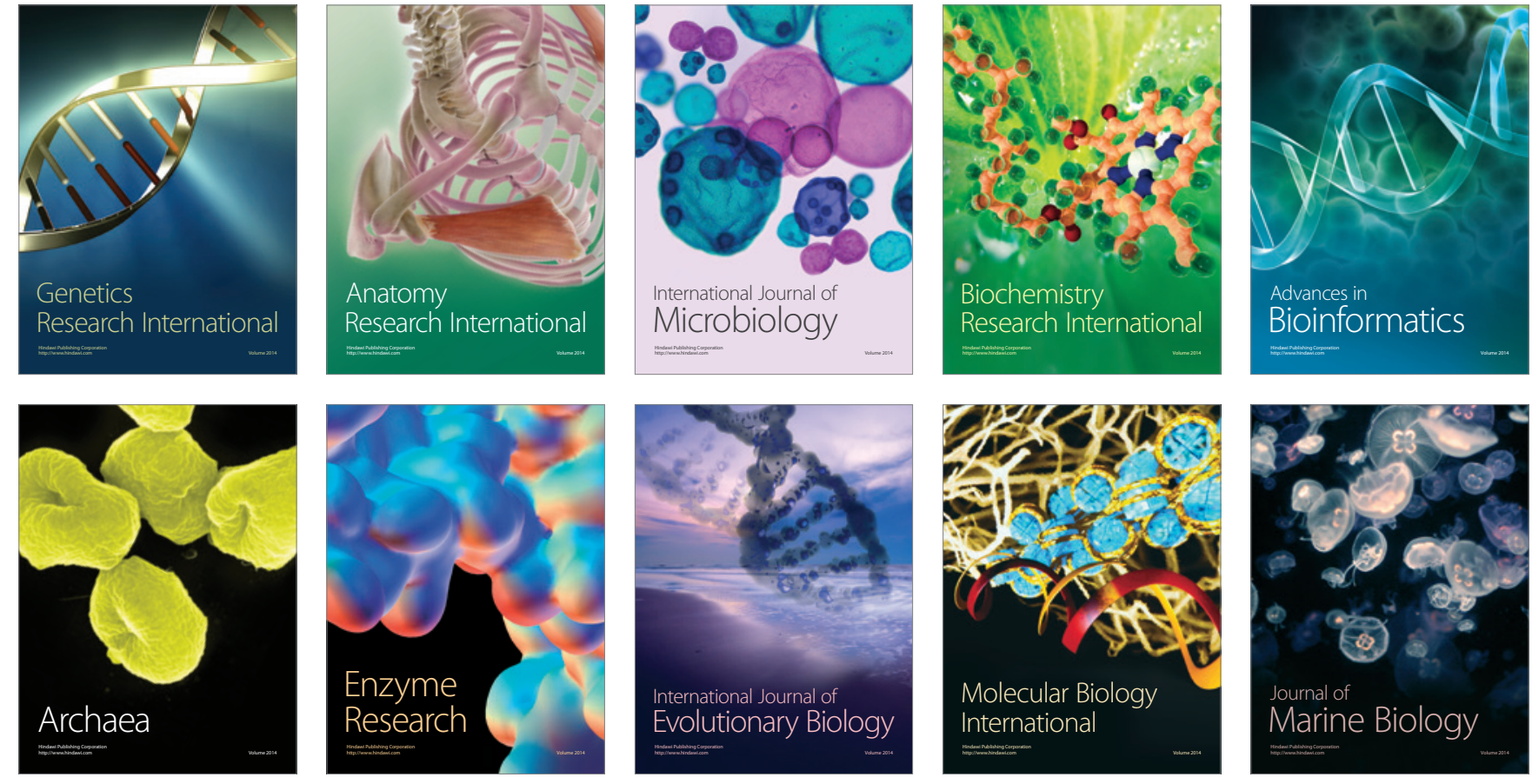